\title{
Menstrual Hygiene Management Practice in Magelang Senior High School
}

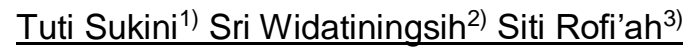 \\ Email : tutisukini@yahoo.com
}

\begin{abstract}
Background: Menstrual Hygiene Management is the management of hygiene and health when women experience menstruation. UNICEF research results state that $46 \%$ of young women in Indonesia change sanitary napkins less than 2 times a day, whereas in theory changing sanitary napkins is at least 3-4 hours a day. Use for more than 8 hours causes genital irritation and itching which will have an impact on health. The purpose of this study was to determine the practice of menstrual hygiene management in high schools in Magelang.

Methods: This research was conducted in 5 public high schools in Magelang. This research method is a mixed methods design. explanatory The research was conducted by collecting quantitative data then qualitative data. The study population was all high school students in Magelang City with a total of 267 respondents.

Results: The results showed that there was a relationship between the peer support variable ( $p$-value 0,000 ), the role of the teacher ( $p$-value 0.002 ), and facilities ( $p$-value 0.003 ) with menstrual health management practices

Conclusion: conclusions and implications for midwifery and nursing practice

All sections in The peer support variable ( $p$ value 0.001 ) had the most influence on menstrual hygiene management. It is hoped that midwives can contribute in providing health education on Menstrual Hygiene Management (MKM) in cross-sectoral collaboration with the Education Office
\end{abstract}

Keyword : Menstrual Hygiene Management (MHM), Senior High Schools.

1,2,3) Politeknik Kesehatan Kemenkes Semarang, Indonesia

Jl. Perintis Kemerdekaan, Magelang, Jawa Tengah, Indonesia

Background. $45 \%$ of Indonesia's population, younger than 25 years, of the total population of 25 million, and nearly 1 in 5 are adolescents aged 10-19 years. Twenty-four million young women in Indonesia have had or will get their first menstruation or menarche (UNICEF, 2015).

Menstrual Hygiene Management (MHM) is the management of hygiene and health when women experience menstruation. Women must be able to use clean sanitary napkins, be able to change sanitary napkins frequently during menstrual periods, and have access to sanitary napkins, and be able to access toilets, soap and water to clean themselves in comfortable conditions with privacy maintained (Anonymous, 2019) .

Menstrual hygiene practice as part of MHM is one of the compulsory activities of School Activities (UKS) related to special requirements for women's hygiene and health during menstruation. Many girls have an inaccurate understanding of menstruation.
Menstruation is a normal biological process even at the time of menarche. Menstruation that is not properly managed can lead to school dropouts, absenteeism, and other sexual and reproductive health problems, with long-term health and socio-economic consequences for adolescent girls (Sinaga et al., 2017)

According to (Suryani, 2019) it is necessary Health promotion to young women, especially about personal hygiene and support from all parties, especially schools and families, is needed in the application of good and correct personal hygiene so that infection in the reproductive organs can be prevented. Inadequate water, sanitation and hygiene facilities in schools is a challenge for students who are menstruating. In addition to insufficient water for washing, small and unsanitary toilets and lack of privacy prevent girls from changing sanitary napkins at school. As a result, some students whose homes are near the school are forced to return home to change their sanitary napkins. Use for more than 8 hours will cause 
irritation and itching on the genitals which will have an impact on health (UNICEF, 2015).

Menstrual Hygiene Management (MHM) is also important for men because it will increase knowledge about the health of the human reproductive system, improve parenting skills, and promote gender equality. It is very important for teachers to provide information about menstruation to male students so that they can be kind to female friends who are menstruating (UNICEF, 2015).

According to research (Rofi'ah, Widatiningsih and Vitaningrum, 2017) health education using the peer group method is effective on the level of knowledge ( $p$ value 0.0001 ) and attitude ( $p$ value 0.0001 ) about personal hygiene during menstruation. It is recommended that teachers and health workers who are in charge of promoting reproductive health in schools use the peer group method to increase the level of knowledge and personal hygiene attitudes of young women during menstruation.

Based on the description above, the researcher is interested in researching "Menstrual Hygiene Management Practices in Public High Schools in Magelang City".

Methods. The research method uses Mixed Methods, with anapproach explanatory research. The research was conducted by collecting quantitative data then qualitative data. This study used a sample of 267 grade XI high school students in Magelang City as respondents. The sample has an age range between 14-18 years. Data analysis used Spearman rank test and multiple logistic regression.

\section{Result and Discussion.}

\section{Relationship between Age and MHM Practices}

The variable age and menstrual hygiene management practices did not have a significant and significant relationship because the sig value was 0.073 ( $p>0.05)$.

Age is one of the factors that can influence a person's behavior. The higher the age, the better the behavior because knowledge and thinking power is increasingly developing. They can distinguish good behavior from bad behavior.

In this study, there was no significant relationship between age and MHM practice, indicated by a $p$ value of 0.073 . The results of this study are in line with research conducted by (Wahyudi, Asmoro and Suarilah, 2018) regarding factors related to personal hygiene during menstruation, the results of the bivariate test $p$ value $=0.473$. This shows that the age of a person's menarche cannot determine their menstrual hygiene practices.

Another study showed that there was no relationship between the age of menarche and personal hygiene during menstruation with a value of $p=0.473$. The results showed that of the 117 respondents, $65.8 \%$ had the ideal age of menarche. However, this is not related to the respondent's personal hygiene during menstruation. Because the more ideal a person's age at menarche does not guarantee that his personal hygiene will be better (Bujawati, Raodhah and Indriyanti, 2017)

Based on some of these studies, an educational method is needed that is adjusted to age level in changing behavior towards supporting health. In this case, self-care during menstruation as well as education that can increase a sense of care for health during menstruation, considering that at this age young women need adequate health information about self-care, but at this age they also have a shy nature to ask questions. The education provided is expected to increase the awareness of young women in caring for health during menstruation. School is one source of information about menstruation with the results of the study stated that more than $80 \%$ of young women get information at school. Menstruation education has been provided by teachers in science, religion and sports subjects.

\section{Relationship between Knowledge and MHM Practices}

The results of the correlation test analysis between knowledge and menstrual hygiene management practices showed that there was no significant and significant relationship because the sig value was 0.058 ( $p>0.05)$.

Menstrual hygiene is personal hygiene in an effort to maintain, maintain and improve one's hygiene and health for physical and psychological well-being through the implementation of hygiene measures during menstruation (Tarwoto and Wartonah, 2010)

Menstrual hygiene is a process of learning outcomes because a woman in this case is a teenager. understand the positive and negative impacts of behavior related to 
menstruation. Based on the results of hypothesis testing between knowledge of menstruation $(\mathrm{X})$ and menstrual hygiene $(\mathrm{Y})$ using theanalysis Pearson product moment , the value ofobtained, $p=0.001 \quad(p<0.05)$ waswhich means that knowledge of menstruation has a significant and positive relationship to hygiene management practices. menstruation in class XI SMA Negeri Magelang City. This is in accordance with the theory in (Peykari et al., 2011) and research (Bujawati, Raodhah and Indriyanti, 2017), that in menstrual hygiene there are factors that influence including the knowledge possessed by these individuals. The knowledge that is meant is knowledge related to menstrual hygiene including knowledge of menstruation, knowledge of reproductive health in women and knowledge of personal hygiene in women both during menstruation and in daily life.

The results of this study are supported by research results (Maulina, 2017) that knowledge about menstruation affectsbehavior personal hygiene during menstruation in teenage students. The same thing was also obtained from the results of research (Wahyudi, Asmoro and Suarilah, 2018) which revealed that there are several factors that play a role in adolescent hygiene behavior during menstruation, among these factors, namely knowledge. The results of this study indicate that knowledge has a significant relationship with hygiene behavior during menstruation with a $p$ value of 0.001 , which means that students with good knowledge will have good hygiene practices during menstruation compared to respondents with less knowledge.

Menstrual knowledge related to menstrual personal hygiene was also shown by the results of research conducted (Butarbutar, 2016) that there was a relationship between knowledge and personal hygiene measures for adolescents during menstruation with a sig-p value $(0.026)<$ sig- $\alpha$ value $(0.05)$. It is the same with research (Maharani and Andryani, 2018) which shows that there is a relationship between knowledge and $p$ value $=0.002$ and $\mathrm{POR}=4.043$. This means that personal hygiene behavior during menstruation is strongly influenced by the knowledge possessed by students. Respondents who have low knowledge mean that they are not able to know, understand and understand the meaning, benefits, and goals of personal hygiene behavior during menstruation. With high knowledge, students will be more motivated for self-hygiene behavior, especially during menstruation.

This is also supported by research conducted by (Pemiliana, Agustina and Verayanti, 2019) that there is a relationship between knowledge and personal hygiene during menstruation. Knowledge of menstruation in class XI students of SMA Negeri Magelang City is based on the median (20), and it can be interpreted that students who score below 20 are 108 respondents $(40.4 \%)$ and those who score above 20 are 159 respondents $(59,6 \%)$.

Knowledge about menstrual hygiene was given programmatically from BK teachers as conveyed by the following informants:

"Implementation of routine decisions every Friday is given" (Informant 1)

"Implementation time is 1 hour every week, for women there are activities every Friday at the PAI lab. . Each class's group turn. " "(Informant 3)

" Implementation of routine decisions given every month "(Informant 5)

" Routine programs in class that have not yet been scheduled but have been planned for each $B K$ teacher. Menstrual topics are given $2 x$ in 1 year "(Informant 4)

\section{Relationship between Support Peers and MHM Practices}

There is a significant and significant relationship between peer support variables and menstrual hygiene management practices because the sig value is $0.000(p<0.05)$ with a weak relationship strength. This is indicated by thevalue correlation coefficient which lies in the range $0.2-<0.4$.

The correlation direction in the Spearman analysis on the above variables is positive, as indicated by thevalue correlation coefficient positive. This means that the direction of the correlation is unidirectional, the greater the value of peer support, the greater the value of menstrual hygiene management practices.

Another factor that is closely related to the practice of MHM namely external factors. Environmental and social as external factors are very supportive of changes in menstrual hygiene individuals, because the environment is a place for the development of individual behavior (Sunaryo, 2013).

The development of adolescent social life is marked by the increasing influence of peers. 
Teens spend more of their time interacting socially with their peers. Peers have a big influence on the attitudes, interests, appearance and behavior of adolescents. This is because communication between peers is easier to digest and accept than communication with parents or those who are more mature than teenagers (Desmita, 2009), (Poltekkes MoH Jakarta I, 2012).

The results of this study, on 267 grade $\mathrm{XI}$ students of SMA Negeri in Magelang City, that there is a significant relationship between peer support and MHM practice. The results of hypothesis testing with the product moment obtained $p=0.000(p<0.05)$, which means that there is a positive and significant relationship between these variables.

In adolescence, very close friendships are bound by the same interests, common interests and share feelings, help each other to solve problems together. In this case the teenagers often get approval (approval) and acceptance(acceptance)of peers. Peers get top priority attention over family. That is why many teenagers are more open to their peers (Sarwono, 2007), (Writers Team for Poltekkes, $\mathrm{MOH}$ Jakarta I, 2012).

The results of the study (Wahyudi, Asmoro and Suarilah, 2018) that there is a relationship between peers and hygiene behavior during menstruation in this study with a value of $p=0.027$ and an $O R$ value $=2.963$ meaning that peer support is 2.963 times the possibility of peers supporting the hygiene behavior of students in during menstruation compared to peers who are not supportive. Thus, it can be concluded that peer support has a great influence on personal hygiene during menstruation. (Peykari et al., 2011) in a peerbased study on the nutritional health of adolescents in Iran, qualitatively showed that peer-based health programs were able to increase the capacity and participation of peer groups in exploring eating habits in adolescents.

The results of this study were supported by research (Zakiudin and Shaluhiyah, 2016) on the Personal Hygiene Behavior of Santri at the Islamic Boarding School in Brebes Regency, it was found that there was a relationship between the support of boarding school caregivers and peers on personal hygiene with the personal hygiene behavior of students at Islamic boarding schools in the Brebes District.
In the mutivariate analysis, based on the results of the correlation analysis test, the sig value was obtained. In the $F$ test of $p=0.000$, it can be concluded that with a $95 \%$ confidence level, knowledge of menstruation and peer communication have a significant effect on the dependent variable of personal hygiene during menstruation.

The results of this study are supported by similar research conducted (Bujawati, Raodhah and Indriyanti, 2017) (Wahyudi, Asmoro and Suarilah, 2018) that simultaneously knowledge and sources of information from peers relate tobehavior personal hygiene menstrual.

The effective contribution of independent variables to the dependent variable can be seen from the adjusted $R$ square value. Adjusted $R^{2}$ The results of this analysis are 0.077 . This means that the effective contribution of menstrual knowledge and peer communication to MHM practice is only 0.077 . This means that the effective contribution of facilities and support from friends for menstrual hygiene management practices is only $7.7 \%$, so $92.3 \%$ is given by other variables.

The results of this study are supported by research (Maharani and Andryani, 2018) that there is a relationship between knowledge, attitudes, the role of health workers, the role of teachers, information sources, and culture with personal hygiene behavior during menstruation among female students at MTs Pondok Pasentren Dar EL Hikmah Kota. Pekanbaru in 2016. This means, apart from peer knowledge and communication, there are other factors that correlate with personal hygiene during menstruation.

The general concept used to diagnose behavior is that of Lawrence Green (Green and Kreuter, 1991). Lawrence Green states that behavior is influenced by three factors: predisposing factors (predisposing factors), enabling factors (enabling factors), factor of the amplifier (reinforcing factors) knowledge, attitudes, and facilities provided sometimes not guarantee a person's behavior or society. With personal experiences and external influences such as friends, it will be able to reinforce behavior.

\section{The Relationship between the Role of Teachers and MHM Practices}

The results of the correlation test analysis between the role of teachers and the practice 
of menstrual hygiene management had a significant and significant relationship because the sig value was $0.002(p<0.05)$ and the strength of the relationship was very weak. This is shown in thevalue correlation coefficient which lies in the range $0.00-<0.2$ (Dahlan, 2015).

The correlation direction in the Spearman analysis on the above variables is positive, as indicated by thevalue correlation coefficient positive. This means that the correlation is unidirectional, the greater the value of the role of the teacher, the greater the value of menstrual hygiene management practices.

The bivariate analysis showed a significant relationship between the teacher's role and MHM practice, with a $p$ value of 0.002 , but in the multivariate analysis there was no significant relationship. This research is supported by research (Maharani and Andryani, 2018) that there is a relationship between knowledge, attitudes, the role of health workers, the role of teachers, information sources, and culture with personal hygiene behavior during menstruation among santriwati at MTs Pondok Pasentren Dar EL Hikmah Kota Pekanbaru Tahun 2016. The

form of teacher's role in increasing knowledge and menstrual health can be in the form of UKS (School Health Business) activities. The School Health Business Development Program (UKS) is an ongoing activity. There are three main programs (Trias UKS), namely health education, health services, and fostering a healthy school environment. The general objective of implementing the UKS program is to instill a clean and healthy lifestyle (PHBS) for students at all levels of primary and secondary education (Directorate of Primary School Development, Dirjen Dikdasmen, 2017). The

obligation to maintain health and hygiene related to menstruation is often neglected. The factors that cause it include ignorance or lack of attention in following what should be done (Sinaga et al., 2017). Parents in this case the teacher must be able to act as a source of information for students. This is in accordance with research (Maharani and Andryani, 2018) which states that teachers have an important role as a source of information so they must provide information that is as clear as possible about knowledge, as well as reproductive health education. Therefore the role of the teacher is a supporting factor for changes in health behavior. Lack of information about personal hygiene during menstruation and a lot of misinformation will make it difficult for students to get and improve healthy behavior. Optimizing the role of teachers in this case in providing good and correct information about personal hygiene behavior during menstruation will improve the quality of personal hygiene behavior for students at Dar El-Hikmah Islamic Boarding School, Pekanbaru City.

\section{Relationship between Facilities and MHM Practices Facility}

variables and menstrual hygiene management practices have a relationship. which is significant and significant because the sig value is $0.003(p<0.05)$ and the strength of the relationship is very weak. This is indicated by thevalue correlation coefficient which lies in the range $0.00-<0.2$.

The correlation direction in the Spearman analysis on the above variables is positive, as indicated by thevalue correlation coefficient positive. This means that the direction of the correlation is unidirectional, the greater the value of the facility, the greater the value of menstrual hygiene management practices.

Menstrual Hygiene Management (MHM) is the management of hygiene and health when women experience menstruation. Women should be able to use sanitary napkins, change them as often as possible, in comfortable conditions with privacy maintained. With the implementation of five effective days of learning in high school, it has an impact on the longer students stay in school. According to (Sinaga et al., 2017) that adequate support is very important, especially in public places such as schools, mosques, tourist attractions, hospitals, stations, markets and others. Unicef's research in 2015 stated that there had been increased awareness of the impact of menstrual management practices on health, education and psychosocial for women and girls in low and middle income countries. Research conducted in Asia, Africa and Latin America describes several challenges faced by women, one of which is insufficient water, sanitation and inadequate facilities. This has an impact on behavior restriction, discomfort for young girls and risks to reproductive health.

The bivariate analysis showed a significant relationship between facilities and MHM practices, with a $\mathrm{p}$ value of 0.003 . This research is supported by research (Zakiudin 
and Shaluhiyah, 2016) that there are 3 (three) independent variables which are proven to jointly influence the personal hygiene behavior of students in Islamic boarding schools in Brebes Regency. The influential variables are gender, the availability of infrastructure about personal hygiene in Islamic boarding schools, and support from friends about personal hygiene because all of them have $p$ value $<0.05$. Of the three independent variables, the variable availability of personal hygiene facilities and infrastructure has the most dominant influence on the personal hygiene behavior of students with an OR value of 10.335. This means that the availability of complete facilities and infrastructure has the possibility of students having good personal hygiene behavior as much as 10.335 times greater than the students whose availability of facilities and infrastructure is incomplete.

The belief and belief that menstruation is dirty or unclean has an impact on MHM practices that are not supported by water, sanitation and hygiene facilities in schools. Almost all girls said they had to wash sanitary napkins before disposing them, but most schools did not provide sufficient water or a separate place for MHM practices. Moreover, only a few schools provide trash cans for disposing of sanitary napkins in the toilet, and young women feel embarrassed when disposing of sanitary napkins. The belief in the dangers of burning sanitary napkins makes young women reluctant to replace or dispose of sanitary napkins at school.

Insufficient water, sanitation and hygiene facilities in schools is also a challenge for girls who are menstruating. In addition to insufficient water for washing, small and unsanitary toilets and lack of privacy make young girls reluctant to change sanitary napkins at school. In this study, SMA in Magelang City has facilitated their students well, the first is about toilet facilities:

"Toilets between girls and boys are separate. Drains almost every day and is always available abate."(Informant 1)

"Toilets between girls and boys are separated. Smooth water. There is a special cleaning team that cleans "(Informant 3)

"The bathrooms for men and women are separate. Smooth water facilities. Disposal when menstruation in every bathroom there is a trash can. In front of each class there is a faucet for washing hands." (Informant 4)
" The bathroom between male and female students is separate. Until now, the water is smooth. Almost in every bathroom there is a trash can. The faucet for washing hands is limited to certain places "(Informant 5)

The second is the facility regarding the devices used by students when menstruating, as listed below:

"If someone is translucent they report borrowing skirts, underwear, and sanitary napkins at the UKS. " (Informant 1)

"Schools, especially in BK prepare sanitary napkins, underwear, skirts" (Informant 2)

"If they are translucent, there are sanitary napkins, skirts, underwear." (Informant 3)

"We always prepare sanitary towels, underwear and skirts. All of that has a budget. "(Informant 4)

The third is the initial treatment when students experience problems during menstruation, as listed below:

"If someone is sick, PMR collaborates with the UKS section which will handle basic medicines. If the pain is unbearable, we take it to the Harapan Hospital closest to the school "(Informant 1)

" UKS provides medicines such as pain medications, and sangobion to prevent anemia. " (Informant 2)

"In UKS there are 2 beds, medicines, sanitary napkins, skirts, underwear." (Informant 3)

". If someone is sick, there are analgesic drugs (pamol, antalgin) but they are not given arbitrarily. if it is unbearable, it is recommended for parents to pick up and rest at the UKS "(Informant 4)

The Influence of Facilities, Age, Knowledge, Friend Support, Teacher's Role with Menstrual Hygiene Management Practices The

independent variable that is included in this multivariate analysis has a value of $p<$ 0.25 , namely facilities, age, knowledge, peer support, and the role of the teacher. The results of the analysis obtained $\mathrm{F}$ count from the facility variable 4,918, age variable 6,163 , peer support 8,043 , and variable teacher role 10,959 with sig value. In each $\mathrm{F}$ test of 0.000 , it can be concluded that with a confidence level of $95 \%$ together the independent variables of facilities, age, peer support, and the role of the teacher have a significant effect on the dependent variable. Menstrual hygiene management practices (MHM)

The $R$ value is 0.277 . This means that there is an effect of facilities and support from friends simultaneously with menstrual hygiene management practices. The effective 
contribution of independent variables to the dependent variable can be seen from the adjusted $R$ square value. The adjusted $R$ Square value in the results of this analysis is 0.077 . This means that the effective contribution of facilities and support from friends for menstrual hygiene management practices is only $7.7 \%$ so that $92.3 \%$ is given by other variables.

The result of the analysis states that the constant value is 11,125 , meaning that if there is no variable support from friends and facilities, the value of MHM practice amounting to 11,125 . The coefficient value is 0.023 , indicating that the increase in knowledge of menstruation is 1 , it will increase the practice of MHM by 0.023 . It can be interpreted that peer support provides big and positive changes to MHM practices. The coefficient value of 0.294 indicates that every 1 increase in the facility variable will give an increase in the value of MHM practice by 0.294 . When compared with peer support, facilities have a greater influence on MHM practice

Conclusion and Suggestions. The Conclusion should answer the objectives of the study or hypothesis. Provide a clear scientific justification for your study, and indicate possible recommendation for midwifery and nursing practice and future practice. Conclusions are stated as paragraphs. Numbering or itemize is not permitted in this chapter.

Acknowledgements Author would like to thank the Poltekkes of the Ministry of Health in Semarang for funding the continuity of the research. We also thank the Principals of Senior High Schools in Magelang City who have provided many suggestions for this research

\section{References.}

Anonymous (2019) Understanding Menstrual Hygiene Management -, www.depkes.go.id. Jakarta. Available at: http://sehatnegeriku.kemkes.go.id/baca/rilis -media/20170526/5821018/mana Manajemen-keburnian-menstruasi-perludip]/.

Bujawati, E., Raodhah, S. and Indriyanti (2017) 'Factors Related to Personal Hygiene During Menstruation in Santriwati at Babul Khaer Islamic Boarding School, Bulukumba Regency, South Sulawesi Province, 2016',
Hygiene, 3 (1).

Butarbutar, MH (2016) 'The Relationship of Knowledge and Attitudes with the Actions of Young Women About Personal Hygiene During Menstruation at SMA Negeri I Sitinjak, Angkola Barat District in 2016', Journal of Public Health and the Environment, 21 (11), pp. 69-78.

Desmita (2009) Developmental Psychology of Students. Bandung: PT Remaja Rosda Karya.

Directorate of Primary School Development, Dirjen Dikdasmen (2017) Menstrual Hygiene Management Guide for Teachers and Parents. Jakarta: Ministry of Education and Culture.

Green, LW and Kreuter, MW (1991) Health Promotion Planning: An Educational and Environmental Approach. 3rd edn. Houston: University of Texas Health Science Center at Houston.

Maharani, R. and Andryani, W. (2018) 'Faktor yang Berhubungan dengan Perilaku Personal Hygiene Saat Menstruasi pada Santriwati di MTs Pondok Pesantren Dar El Hikmah Kota Pekanbaru', Jurnal Kesmas, 1(1), pp. 69-77. doi: 10.31539/kesmars.v1i1.172.

Maulina, N. (2017) 'HUBUNGAN PENGETAHUAN DAN SIKAP REMAJA PUTRI DENGAN PERSONAL HYGIENE SAAT MENSTRUASI PADA SISWI KELAS IX DI SMP NEGERI 1 LHOKSEUMAWE TAHUN 2016', Jurnal Ilmiah Sains, Teknologi, Ekonomi, Sosial, dan Hudaya, 1(1), pp. 74-79.

Pemiliana, PD, Agustina, W. and Verayanti, D. (2019) 'Perilaku Remaja Putri Dengan Personal Hygiene Saat Menstruasi Di Sma Etidlandia Medan Tahun 2018', Gaster : Jurnal Kesehatan, 17(1), pp. 62-76. doi: 10.30787/gaster.v17i1.341.

Peykari, N. et al. (2011) 'A peer-based study on adolescence nutritional health: A lesson learned from Iran', Journal of the Pakistan Medical Association, 61(6), pp. 549-554.

Rofi'ah, S., Widatiningsih, S. and Vitaningrum, D. (2017) 'Kesehatan Metode Peer Group Dan Sikap Personal Hygiene Saat', Jurnal IImiah Bidan, II(2), pp. 31-36. Available at: https://media.neliti.com/media/publications/ 227226-efektivitas-pendidikan-kesehatanmetode-1c5102d8.pdf.

Sarwono, SW (2007) Psikologi Remaja. Jakarta: Raja Grafindo Persada. 
Sinaga, E. et al. (2017) Manajemen Kesehatan Menstruasi. Universitas Nasional IWWASH Global One.

Sunaryo (2013) Psikologi untuk Keperawatan. Jakarta: Penerbit Buku Kedokteran EGC.

Suryani, L. (2019) 'FAKTOR-FAKTOR YANG MEMPENGARUHI PERILAKU REMAJA PUTRI TENTANG PERSONAL HYGIENE PADA SAAT MENSTRUASI', Journal of Midwifery Science, 3(2), pp. 24-35.

Tarwoto and Wartonah (2010) Kebutuhan Dasar Manusia dan Proses Keperawatan. 4th edn. Jakarta: Salemba Medika.

Tim Penulis Poltekkes Depkes Jakarta I (2012) Kesehatan Remaja, Problem dan Solusinya. Jakarta: Salemba Medika.
UNICEF (2015) Manajemen Kebersihan Menstruasi di Indonesia. Jakarta: Aliansi Remaja Independen Wahyudi, A. setiya, Asmoro, CP and Suarilah, I. (2018) 'Faktor yang Berhubungan dengan Personal Hygiene Saat Menstruasi', Jurnal Kesehatan Manarang, 4(2), pp. 104-113.

Zakiudin, A. and Shaluhiyah, Z. (2016) 'Perilaku Kebersihan Diri (Personal Hygiene) Santri di Pondok Pesantren Wilayah Kabupaten Brebes akan Terwujud Jika Didukung dengan Ketersediaan Sarana Prasarana', Jurnal Promosi Kesehatan Indonesia, 11(2), p. 64. doi: 10.14710/jpki.11.2.64-83. 